\title{
GÖÇMEN ÇOCUKLARIN TÜRKÇE ÖĞRENIMINDE YAŞADIKLARI PROBLEMLER
}

\section{ARAŞTIRMA MAKALESI}

\author{
Mehmet TURAN', Mehmet FANSA² \\ 1 Prof, Dr. Hatay Mustafa Kemal Üniversitesi, Temel Eğitim, mturan@mku.edu.tr, ORCID: 0000-0001-6963-4827. \\ 2 Dr. MEB, Temel Eğitim, mfansa84@gmail.com, ORCID: 0000-0001-5770-797X.
}

Geliş Tarihi: 28.06.2021 Kabul Tarihi: 24.08.2021 DOI: 10.37669 milliegitim.958878

Öz: Bu araştırma, Suriye'deki savaş ortamından kaçarak Türkiye'ye sığ1nan ilkokul eğitim çağındaki çocukların Türkçe öğrenme sürecinde yaşadıkları problemleri betimlemeyi amaçlamaktadır. Araştırmada betimsel tarama modeli tercih edilmiştir. Araştırma grubunu, 2020-2021 eğitim-öğretim yılında Hatay ili Reyhanlı ilçesindeki sekiz ilkokulda eğitim alan 4.sınıf düzeyindeki 160 Suriye uyruklu öğrenci oluşturmaktadır. Araştırmada göçmen çocukların Türkçe öğreniminde yaşadıkları problemlerin belirlenmesi amacıyla örnek veri toplama formu geliştirilmiştir. Veriler, geliştirilen anketin öğrencilere uygulanmasıyla toplanmıştır. Anket aracılığı ile elde edilen veriler; frekans dağılımları, yüzde (\%)hesaplamaları, aritmetik ortalamaları, kikare ve bağımsız gruplar $\mathrm{t}$ testi SPSS programında çözümlenerek analiz edilmiştir. Verilerinin analizi sonucunda; Türkçede yer alan Arapça kökenli kelimelerin öğrencilerin Türkçe öğrenme sürecini kolaylaştırdığı, öğrencilerin öğretim kitaplarını ve öğretmenlerini yeterli olarak değerlendirdikleri, Türkçe konuşmada zorluk yaşamadıkları ancak yazılı anlatımda zorlandıkları sonucuna ulaşılmıştır. Ayrıca, öğrencilerin görüşlerinden Arapça metinleri Türkçe çeviri yapabildikleri, duygu ve düşüncelerini Türkçe cümle kurarak anlatabildikleri ancak Türkçe dersi almadan Türkçe öğrenemeyecekleri anlaşılmaktadır. Suriyeli göçmen öğrenciler, sesli harflerde en çok sırasıyla "ü-ö-u-i", sessiz harflerde ise en çok " "̆-ş-j-ç" harflerini seslendirmede zorluk yaşarken d sesini seslendirmede hiç sorun yaşamamaktadır. Araştırma bulguları, Suriyeli göçmen öğrencilerin Türkçe öğrenme sürecinde yaşadığı sorunları betimlemekte ve bu sorunlara yönelik çözüm önererek sahaya ilişkin daha kapsamlı bilgiler sunmaktadır. Araştırma; dil beceri alanlarından konuşma becerisine yönelik daha çok çalışmalar yapılmasını ve sesli ve sessiz harflerin öğretimini pekiştirecek seslendirme çalışmalarının yapılmasını önermektedir.

Anahtar Kelimeler: Yabancılara Türkçe Öğretimi, Geçici Koruma, Suriyeli Göçmen Öğrenci 


\title{
PROBLEMS EXPERIENCED OF MIGRANT CHILDREN IN LEARNING TURKISH
}

\begin{abstract}
:
This research aims to describe the problems in the process of learning Turkish experienced by primary school children who fled the war in Syria and sought refuge in Turkey. In the research, the descriptive survey model was preferred. The research group consists of 160 Syrian students at the 4th grade level who were educated at eight primary schools in Reyhanlı district of Hatay province in the 2020-2021 academic year. In the research, a sample data collection form was developed to determine the problems that migrant children experience in Turkish learning. The data were collected by applying the developed survey to the students. Data obtained through the survey; frequency distributions, percentage $(\%)$ calculations, arithmetic averages, chi-square and independent samples $t$ test were analyzed in SPSS program. As a result of the analysis of the data; It has been concluded that the words of Arabic origin in Turkish facilitate the Turkish learning process of the students, that the students evaluate the textbooks and their teachers adequately, that they do not have difficulty in speaking Turkish, but that they have difficulties in written expression. In addition, it is understood from their opinions that students can translate Arabic texts to Turkish, express their feelings and thoughts in Turkish sentences but they can't learn Turkish without taking Turkish lessons. Syrian migrant students have difficulty vocalizing the letters respectively, "ü-ö-u-i" in vowels and "ğ-ş-j-ç" in consonants while they have no problem vocalizing the " $\mathrm{d}$ " sound. The research findings describe the problems experienced by Syrian migrant students in the Turkish learning process and offer more comprehensive information on the field by suggesting solutions to these problems. The research suggests that more studies should be conducted on speaking skills from the skill areas of language skills and voice-over studies that will strengthen the teaching of vowels and consonants.
\end{abstract}

Keywords: Teaching Turkish to Foreigners, Temporary Protection, Syrian Migrant Student.

\section{Giriş}

İnsanlar, geçmişten günümüze eğitim, ekonomi, farklı kültürleri tanıma ve göç gibi sebeplerle yabancı dil öğrenme ihtiyacı hissetmişlerdir. Suriye'de 2011 yılında başlayan iç savaş sonucunda milyonlarca kişi Türkiye'ye göç etmiş ve bu kişiler Türkiye'de geçici koruma altına alınmıştır. Türkiye'ye gerçekleşen Suriye göçü ile Türkçeye duyulan ilgi de son yıllarda artmıştır. Türkiye'nin Suriye sınırındaki şehirler, Suriye göçün- 
den en çok etkilenen iller olmuştur. Göç İdaresi Genel Müdürlügüünün verilerine göre araştırmanın uygulandığ ${ }_{1}$ Hatay, 436.708 kişi ile geçici koruma kapsamındaki Suriyeli kişilere en çok ev sahipliği yapan Türkiye'nin 3. ilidir (GİGM, 2020). Göç sonrasında barınma, konaklama, beslenme gibi temel ihtiyaç sorunlarının yanı sıra öğrenim çağındaki Suriyeli çocukların eğitimleri de çözülmesi gereken acil sorunların başında gelmiştir.

Suriyeli göçmen çocuklar, yaşadıkları savaş sonrasında ülkelerinin yanı sıra okul yaşamlarından da mahrum kalmışlardır. Göç sonrasında çocuklarının Türkiye'ye eğitime devam etmesini isteyen Suriyeli aileler, geçici eğitim merkezleri [GEM] kuruluna dek çocuklarını Kuran kurslarına veya Sivil Toplum Kuruluşları [STK] aracılığı ile hukuki alt yapısı olmadan açılan okullara göndermişlerdir. Milli Eğitim Bakanlığı [MEB], 2014/21 sayılı genelge doğrultusunda eğitimlerine ara vermek zorunda kalan veya hiç okula gitmeyen Suriyeli çocukların eğitime erişimlerini sağlamak amacıyla göçmen nüfusunun yoğun olduğu şehirlerde GEM'leri açmıştır. Savaş mağduru olan çocuklar, bu merkezlerde 15 saat Türkçe ve 15 saat Arapça ders alarak ara verdikleri eğitimlerine devam etmişlerdir. Ancak çocukların dilini ve kültürünü bilmedikleri yeni yaşam düzeni ile karşılaşmaları, onların eğitime uyum sürecinde sorun yaşamasına neden olmuştur. Bu sorunların başında da dil sorunu gelmektedir. Beyazova-Seçer (2017) Suriyeli ailelerin Türkçe bilmemekten kaynaklı dil engelleri yaşadıklarını; Cin (2018) sınıfında Suriyeli öğrencisi olan sınıf öğretmenlerinin en sık karşılaştığı sorunun da dil sorunu olduğunu ifade etmiştir.

GEM'lerin açılmasından iki yıl sonra da MEB Temel Eğitim Genel Müdürlüğü'nün 19/08/2016 tarihli ve 8902788 sayılı yazısı ile geçici koruma kapsamındaki çocukların kademeli olarak devlet okulunda eğitim alabileceğini bildirmiştir. MEB'in ilgili yazıda, 2016-2017 eğitim öğretim yılında anasınıfı ve ilkokul 1. sınıfa gidecek durumda olan Suriyeli çocukların kayıtlarının Bakanlığa bağlı okullara yapılacağını açıklamıştır (MEB, 2016). Suriyeli çocuklar, geçici eğitim merkezleri ile birlikte 1. Sınıftan itibaren kademeli olarak devlet okullarında eğitim almaya başlamıştır. MEB, GEM'leri açmasının yanı sıra geçici koruma kapsamındaki çocukların Türkçe öğrenmesi için Suriyeli Çocukların Türk Eğitim Sistemine Entegrasyonun Projesi'ni [PICTES] başlatmış ve geçici eğitim merkezlerinde PICTES projesi tarafından görevlendirilen Türkçe öğreticileri tarafından çocukların Türkçe eğitim almalarını sağlamıştır. Ancak 2020 yılında Türkiye'deki tüm GEM'ler kapatılmış ve Suriyeli çocuklar eğitimlerine devlet okullarındaki sınıflarda devam etmişlerdir. Suriyeli göçmen çocukların devlet okullarında eğitim alması ile göçmen çocukların Türkçe öğrenimde yaşadığı problemlerin betimleme ihtiyacı daha da artmıştır.

\section{Geçmişten Günümüze Yabancılara Türkçe Öğretimi}

Türkçenin Türkiye'de yabancı dil olarak öğretilmesinde iki temel kurum öne çımaktadır. Bu kurumların başında Türkçe ve Yabancı Diller Araştırma ve Uygulama 
Merkezi (TÖMER) gelmektedir. TÖMER, 1984 yılında Ankara Üniversitesi'nin yabancılara Türkçe öğretimi bölümü olarak kurulmuş ve 1980'lerde Türkçeyi yabancı dil olarak öğreten ilk ve tek kurum olmuştur. TÖMER aynı zamanda Yeni Hitit Yabancılar için Türkçe eğitim serisi adlı yayını ile yabancılara Türkçe öğretimi için dil öğrenme setlerini hazırlamıştır. Türkiye'de Türkçeyi yabancı dil olarak öğreten ikinci kurum ise 2007 yılında kurulan Yunus Emre Enstitüsü'dür. TÖMER gibi Yunus Emre Enstitüsü de Türkçenin öğretimi amacıyla yabancılara Türkçe Öğretim setleri hazırlamıştır. Yunus Emre Enstitüsünün 2016-2017 eğitim-öğretim yılında çocuklara yönelik 6-12 yaş grubu için Yabancılar İçin Türkçe Öğretimi programları hazırlanmıştır. Bu yayınlar Türkiye'de açılan GEM'lerde ders materyali olarak kullanılmıştır. Bu kapsamda Yunus Emre Enstitüsünün Yabancılara Türkçe Öğretimi kitap setinden 490.000 adet satın alınmış ve Suriyeli öğrencilere dağıtılmıştır (MEB, 2017). MEB tarafından dağıtılan Türkçe Öğreniyorum seti, GEM'lerdeki 2.sınıftan 12 sınıfa kadar tüm sınıf düzeylerinde uygulanmıştır. Ancak GEM'ler kapatıldıktan sonra çocuklar, devlet okulunda eğitim almaya başlamış ve bu öğrenim setleri yerine çocuklar sınıf seviyelerindeki öğretim programlarına göre Türkçe eğitimlerini almışlardır.

Türkçenin yabancı dil olarak öğretiminin geçmişine bakıldığında Araplara Türkçe öğretiminin çok eski zamanlara dayandığı görülmektedir. Divanü Lügat-it-Türk, Araplara Türkçe öğretmek amacıyla yabancılara Türkçe öğretimi konusunda yazılan ilk eser olma özelliğini taşımaktadır (Barın, 1992). Türkçenin yabancı dil olarak öğretilmesi geçen yüzyılın son çeyreğinden itibaren çeşitli açılardan kapsamlı bir şekilde ele alınmaya başlanmıştır. Bu alanda yapılan çalışmaların özellikle son on yılda arttığ ve genellikle dil bilgisel, eğitim bilimsel, kültürel ve sorun temelli konular üzerinde durduğu söylenebilir (Alyılmaz, 2018; Bakır, 2014; Candaş Karababa, 2009; Er, Biçer ve Bozkırlı, 2012; Göçer ve Moğul, 2011; Kahriman, Dağtaş, Çapoğlu ve Ateşal, 2013; Gürbüz ve Güleç, 2016; Seymen ve Tok, 2015). Benzer biçimde yabancılara yönelik Türkçe öğretiminde öğretim programı ve teknolojik imkânlarda karşılaşılan yetersizlikler, kaynak ve materyallerdeki eksiklikler, kurumlar arası koordinasyon eksikliği, öğretim elemanlarının yeterli donanıma sahip olmaması ve Türkçe öğretiminin farklı ana bilim dallarına ayrılmamış olması gibi sorunlara dikkat çekmektedir (Er, Biçer ve Bozkırlı, 2012).

Türkiye'de geçici koruma kapsamındaki Suriyeli öğrencilerin eğitimi ile ilgili yapılan araştırmalarda; Gözübüyük (2017) okul yöneticilerinin Suriyeli öğrencileri okula kayıt etme sürecinde, öğretmenlerin öğrencilerle iletişim kurmada dil kaynaklı sorun yaşadığını; Levent ve Çayak (2017) okul yöneticilerin veliler ile dil kaynaklı iletişim sorunu yaşadığını, öğrencilerin yabancı tanıtım belgesi ve denklik belgelerinin olmadığını; Fansa (2015), Türkçe öğretim alanı ile ilgili kaynak çeşitliliğinin az olduğunu ve Türkçe öğretimin alan uzmanları tarafından gerçekleştirilmesi gerektiğini ortaya koymuştur. Topsakal, Merey ve Keçe (2013) branş ve sınıf öğretmenlerinin göçle gelen öğrencilerin yaşadıkları en büyük sorunların dil, okulun sınıfın kurallarına uymakta 
zorlanma, derslere geç başlama ve derslerde başarısız olma olduğunu; Mercan Uzun ve Bütün (2016) çocukların Türkçe bilmemeleri nedeniyle ciddi sorunlar yaşadıklarını ve birbirleriyle iletişim kuramadıklarını, yalnızlaştıklarını; Tanay-Akalın (2016) öğrencilerin sınıflarda yaşadıkları sorunları genel olarak arkadaşlarıyla kavga ve geçimsizlik, derslere karşı ilgisiz olma, ekonomik sorunlar ve iletişim kurma olduğunu; Avcı, Koçoğlu ve Ekici (2013) okul yöneticilerinin göçle gelen ailelerde karşılaşılan en büyük sorunun dil, iletişim ve uyum sorunu olduğunu, buna bağlı olarak öğrencilerin davranış bozuklukları geliştirdiklerini ve derslerinde başarısız olduklarını ifade etmişlerdir. Bu bağlamda, Türkçe öğrenimi ve öğretimi sürecindeki sorunların betimlenerek alana çözüm önerilerinin sunulması gerektiği alanyazın çalışmalarından da anlaşılmaktadır.

\section{Yabancılara Türkçe Öğretiminde Öğretmen Yeterlilikleri}

Öğretmenlerin sığınmacı veya geçici koruma kapsamındaki çocuklara yönelik eğitim uygulamalarında sosyokültürel bilgiye sahip olması önemlidir. Mülteci kökenli çocuklar, yaşadıkları travma nedeniyle farklı öğrenme gereksinimlerine sahip olurlar (Brown vd., 2006; Kanu, 2008; Stewart, 2011). Mülteciler sürekli artarken mültecilere ev sahipliği yapan ülkelerin çoğu, öğretmenlere mültecilerin eğitimi üzerine özel bir eğitim vermemekte ve öğretmenler kendi deneyimleri ile öğrenmektedir (Mcbrien, 2005). Öğretmenler, genellikle mesleki gelişimdeki yetersizlik ve eğitim ekipmanlarındaki eksiklik gibi konulardan dolayı çocuklara ve gençlere eğitim vermede kendilerini hazırlıksı hissetmektedir (Gunderson, 2007; Stewart, 2007, 2011; Whiteman, 2005). Bu durum öğretmenleri, yabancı oldukları eğitim ortamlarında zor durumda bırakabilmektedir. Kimi öğretmenlerin davranış problemleriyle başa çıkmaya hazır olmamas1nın yanı sıra sorunun nasıl ele alınacağı konusunda da başarısız olduğu görülmektedir (Al-qdah ve Lacroix, 2010). Öğretmenlerin çokdilli ve çokkültürlü sınıflarda farklı öğrenme ihtiyaçları olan öğrencilerin eğitimi konusunda desteklenmesi gerekmektedir (Aykırı, 2017; Ereş, 2015; Sakız, 2016; Saklan ve Erginer, 2017; Tösten vd., 2017). Eğitim sisteminde, sığınmacı ve mülteci çocukların eğitimi, sınıfta farklılıkların yönetimi gibi konularda öğretmenlere mesleki gelişimlerini artıracak hizmet içi eğitimler düzenlenmelidir (Sakız, 2016, s. 75). Araştırma, çocukların öğretmenlerin Türkçe öğretme yeterlilikleri ile ilgili düşüncelerini de ortaya çıkaracağından bulguların alanyazına katkısının olacağı düşünülmektedir.

Araştırma, Hatay ili Reyhanlı ilçesinde eğitim alan 4. sınıf düzeyindeki Suriye uyruklu çocukların Türkçe öğrenme sürecinde yaşadığı sorunları betimlemeyi ve bu sorunlara yönelik çözüm önerileri geliştirmeyi amaçlamaktadır.

Hatay ilinde geçici koruma kapsamındaki çocukların eğitim aldıkları geçici eğitim merkezleri 2020 yılında kapatılmış ve Suriye uyruklu tüm göçmen çocuklar, eğitimlerine devletin resmi okullarında devam etmişlerdir. Alanyazında da belirtildiği üzere geçici koruma kapsamındaki Suriyeli çocukların eğitim entegrasyonunda, akademik başarılarında, yerli akranları ile güçlü iletişim kurmasında Türkçe bilmenin ve öğren- 
menin gerekliliği anlaşılmaktadır. Bu durum, Türkçe öğrenen çocukların dil öğrenme sürecinde yaşadığı problemleri anlamanın önemine işaret etmektedir. Bu araştırma ile göçmen öğrencilerin Türkçe öğrenme süreçlerinde karşılaştı̆̆ bilişsel ve duyuşsal problemlerin belirlenmesi, bulgular ışığında alana çözüm önerilerinin sunulması ve yabancılara Türkçe öğretim sürecinin daha etkili biçimde yürütülmesi beklenmektedir.

\section{Yöntem}

\section{Araştırma modeli}

Araştırma, göçmen öğrencilerin Türkçe öğrenme sürecinde yaşadığ1 sorunları ortaya çıkaracağından çalışmada betimsel tarama modeli tercih edilmiştir.

\section{Evren Örneklem}

Araştırma evrenini, Türkiye'de Türkçeyi ikinci dil olarak öğrenen Suriye uyruklu öğrenciler oluşturmaktadır. Çalışmada örneklem seçiminde basit seçkisiz örnekleme yöntemi kullanılmıştır. Bu örnekleme, evrendeki her birimin örnekleme girme olas1lığının eşit ve birbirinden bağımsız olduğu bir örneklemedir. Bu özelliklerden dolayı, sonuçlar (örneklem büyüklüğü de uygunsa) evrene genellenebilir (Erkuş, 2005; Nachimas ve Nachimas, 1996). Bu bağlamda araştırmanın örneklemini, 2020-2021 eğitim-öğretim yılında Hatay ili Reyhanlı ilçesindeki sekiz ilkokulda eğitim alan 4.sınıf düzeyindeki 160 Suriye uyruklu öğrenci oluşturmaktadır. Araştırmacıların uzmanlık alanları sınıf öğretmenliği bölümü olduğundan araştırma grubu ilkokul düzeyi olarak belirlenmiştir.

\section{Araştırmaya Katılan Öğrencilerin Cinsiyet Dağılımı}

Araştırmaya katılan öğrencilerin cinsiyetlerine göre frekans ve yüzde dağılımları Tablo 1'de verilmiştir.

Tablo 1. Araştırmaya katılanların cinsiyetlerine göre dağılımı

\begin{tabular}{llll}
\hline & & $\mathrm{f}$ & $\%$ \\
\hline \multirow{3}{*}{ Cinsiyet } & Erkek & 86 & 53.8 \\
& Kiz & 74 & 46.3 \\
& Toplam & 160 & 100 \\
\hline
\end{tabular}

Araştırmaya toplam 160 öğrenci katılmıştır. Öğrencilerin cinsiyetlerine göre katılım oranları incelendiğinde; 160 öğrenciden \%53.8'inin (86) erkek, \%46.3'ünün (74) kız olduğu tespit edilmiştir.

\section{Verilerin Toplanması}

Araştırmada göçmen çocukların Türkçe öğreniminde yaşadıkları problemlerin belirlenmesi amacıyla örnek veri toplama formu geliştirilmiştir. Geliştirilen formun 
hazırlanma aşamasında ilk önce yabancılara Türkçe öğretimi konusunda alanyazındaki çalışmalar incelenmiştir. Hazırlanan anket formundaki 14 soru maddesinden 5 olumsuz madde $(1,9,10,11,12)$ ters döndürülmüş ve yapılan faktör analizi sonucunda KMO: 0.70 Bartlett: 546.712 ve güvenirlik katsayısı alpha: 0.706 olarak bulunmuştur. Hazırlanan veri toplama formunun alan uzmanları tarafından incelenmesi neticesinde ankete son şekli verilmiştir. Araştırmada "Göçmen Çocukların Türkçe Öğreniminde Yaşadıkları Problemleri" betimleyen anket formunun ilk bölümünde, öğrencilerin demografik (cinsiyet) bilgileri; ikinci bölümünde ise 5'li likert biçiminde hazırlanan 14 soru, 4'lü likert biçiminde 1 soru ve açık uçlu biçimde bir soru olmak üzere toplam 16 soru yer almaktadır. Araştırma sürecine iliş̧in bilgiler ve anket formu, Hatay Mustafa Kemal Üniversitesi Rektörlüğü Sosyal ve Beşeri Bilimler Bilimsel Araştırma ve Yayın Etiği Kurulunun 05.04.2021 tarih ve 17 sayılı kararı ile uygun görülmüştür. Etik kurul kararının ardından Hatay İl Milli Eğitim Müdürlüğünden 16.06.2021 tarih ve 26578457 sayılı kararı ile araştırmanın uygulanması için araştırma izni alınmıştır. Araştırma verileri, geliştirilen formun öğrencilere uygulanmasıyla toplanmıştır. Araştırma grubu, çalışmaya tamamen gönüllülük esasına dayalı katılmıştır. Bu araştırmadan elde edilen veriler, tamamen araştırma amacı ile kullanılacak olup kişisel bilgiler gizli tutulmuştur.

\section{Verilerin Analizi}

Anket aracılığı ile elde edilen verilerin frekans, yüzde dağılımları, aritmetik ortalamaları hesaplanmış, kikare ve bağımsız gruplar t-testi ile çözümlenmiştir. Verilerin analizi sonucunda göçmen çocukların Türkçe öğrenme sürecinde yaşadığı problemler betimlenmiş ve sorunlara yönelik çözüm önerileri sunulmuştur. Araştırmada uygulanan ankete katılımcıların gerçek beceri, duygu ve düşüncelerini yansıttığı düşünülmektedir. Araştırmada geliştirilen anket, çocukların Türkçe öğrenme sürecinde yaşadıkları sorunları ortaya çıkarmıştır. Araştırmanın ilkokul 4. sınıf öğrencileri üzerinde yapılması, Hatay ili Reyhanlı İlçesindeki sekiz ilkokulda 160 öğrenci ile yürütülmesi araştırmanın sınırlılıkları arasındadır.

\section{Bulgular}

Bu bölümde veri toplama formunun uygulanmasiyla elde edilen bulgu ve yorumlara yer verilmiştir. Verilerin analizi sonucunda; Türkçe öğrenme sürecinde öğrenme alanlarında yaşadıkları zorluklara, öğrenme alanlarındaki zorlukların cinsiyet değişkenine göre farklılığına, öğrencilerin Türkçe öğreniminde yaşadıkları problemlere, Türkçe öğreniminde yaşanılan problemlerin cinsiyet değişkenine göre dağılımına, öğrencilerin Türkçe öğrenme sürecinde seslendirmede zorlandıkları sesli ve sessiz harflere ilişkin bulgulara ulaşılmıştır. 


\section{Göçmen Öğrencilerin Türkçe Öğrenme Sürecinde Zorluk Yaşadıkları Öğrenme Alanları}

Araştırmaya katılan öğrencilerin Türkçe öğrenimlerinde zorluk yaşadıkları alanlara ilişkin öğrenci görüşlerinin frekans ve yüzdelik değerleri Tablo 2'de verilmiştir.

Tablo 2. Araştırmaya Katılan Öğrencilerin Türkçe Öğrenme Sürecinde Zorluk Yaşadıkları Öğrenme Alanları

\begin{tabular}{llll}
\hline & & $\mathrm{f}$ & $\%$ \\
\hline & Okuma-Anlama & 34 & 21.3 \\
& Yazılı Anlatım & 23 & 14.4 \\
Öğrenme Alanları & Sözlü Anlatım & 47 & 29.4 \\
& Hepsi & 56 & 35.0 \\
& Toplam & 160 & 100 \\
\hline
\end{tabular}

Öğrencilerin en çok zorluk yaşadığı alanlar sırasıyla; ankette belirlenen üç öğrenme alanının tümü (56), sözlü anlatım (47), okuma-anlama (34) ve yazılı anlatım (23) olarak tespit edilmiştir. Burada ulaşılan bulgu ile öğrencilerin sözlü anlatım becerilerinde yazılı anlatıma göre daha çok zorlandıkları söylenebilir.

Göçmen Öğrencilerin Cinsiyet Değişkenine Göre Türkçe Öğrenme Sürecinde Zorluk Yaşadıkları Öğrenme Alanları

Araştırmada Türkçe öğrenme sürecinde zorluk yaşanılan öğrenme alanları, göçmen öğrencilerin cinsiyet değişkenine göre de incelenmiştir. Araştırmaya katılan öğrencilerin cinsiyet değişkenine göre Türkçe öğrenme sürecinde zorluk yaşadıkları alanlara ilişkin dağılım Tablo 3'te verilmiştir.

Tablo 3. Araştırmaya Katılan Öğrencilerin Cinsiyet Değişkenine Göre Türkçe Öğrenme Sürecinde Zorluk Yaşadıkları Öğrenme Alanları

\begin{tabular}{lcccccc}
\hline \multirow{2}{*}{ Öğrenme Alanları } & \multicolumn{2}{c}{ Erkek } & \multicolumn{2}{c}{ Kız } & \multirow{2}{*}{$X^{2}$} & P \\
\cline { 2 - 5 } & f & $\%$ & f & $\%$ & & \\
\cline { 2 - 5 } Okuma-Anlama & 27 & 31.4 & 7 & 9.5 & & \\
Yazılı Anlatım & 11 & 12.8 & 12 & 16.2 & & 0.003 \\
Sözlü Anlatım & 18 & 20.9 & 29 & 39.2 & & \\
Hepsi & 30 & 34.9 & 26 & 35.1 & & \\
Toplam & 86 & 100 & 74 & 100 & & \\
\hline
\end{tabular}

${ }^{*} \mathrm{p}<.005$ 
Tablo 3 incelendiğinde göçmen öğrencilerin Türkçe öğrenme sürecinde zorluk yaşadıkları alanların tespitine ilişkin yapılan kikare testi sonucunda öğrencilerin cinsiyet değişkenine göre $\mathrm{p}<.005$ düzeyinde anlamlı farklılık tespit edilmiştir $\left(X^{2}=13.846\right.$ $\mathrm{p}<.003)$. Buna göre veriler, cinsiyet değişkenine göre incelendiğinde, okuma-anlamada; erkek öğrencilerin \%31.4'ünün, kız öğrencilerin ise \%9.5'inin zorluk yaşadıkları tespit edilmiştir. Yazılı anlatım alanında; kız öğrencilerin \%16.2'si, erkek öğrencilerin \%12.8'i zorlandıklarına yönelik görüş belirtse de bulguda ulaşılan oranlarının birbirine yakın olduğu görülmektedir. Sözlü anlatım alanında; kız öğrencilerin \%39.2'si erkek öğrencilerin \%20.9'u zorlandıklarını belirtmişlerdir. Anketteki üç öğrenme alanlarında yaşanılan zorluklar cinsiyet değişkenine göre değerlendirildiğinde; k1zların \%35.1'inin erkeklerin \%34.9'unun zorluk yaşadıkları ve oranların kız ve erkek değişkeni açısından birbirine yakın olduğu görülmüştür.

\section{Göçmen Çocukların Türkçe Öğreniminde Yaşadıkları Problemler}

“Göçmen Çocukların Türkçe Öğreniminde Yaşadıkları Problemleri” betimlemek için ankette yer alan ifadelerin yanıtları, 5'li likert biçiminde düzenlenmiştir. Anket maddelerinde öğrenci görüşleri; "1-Tamemen Katılıyorum, 2-Katılıyorum, 3-Kısmen katılıyorum, 4- Katılmıyorum, 5- Hiç katılmıyorum” biçiminde beş seçenek yer almaktadır. Göçmen çocukların Türkçe öğreniminde yaşadıkları problemlere ilişkin elde edilen sonuçlar Tablo 4 'te verilmiştir.

Tablo 4. Göçmen Çocukların Türkçe Öğreniminde Yaşadıkları Problemlere İlişkin Elde Edilen Sonuçlar

\begin{tabular}{lrc}
\hline \multicolumn{1}{c}{ Göçmen Çocukların Türkçe Öğreniminde Yaşadıkları Problemler } & $\bar{X}$ & SS \\
\hline 1. Türkçe öğrenebilmek için yeterli sayıda kitabım yoktur. & 3.45 & 1.55 \\
2. Öğretmenlerimiz Türkçe öğretiminde yeterlidir. & 4.14 & 1.09 \\
3. Fırsat buldukça Türkçe konuşurum. & 3.73 & 1.29 \\
4. Türkçeyi kolaylıkla konuşabilirim. & 3.94 & 1.15 \\
5. Arapça metinleri Türkçeye çevirebilirim. & 3.58 & 1.34 \\
6. Duygu ve düşüncelerimi Türkçe anlatabilirim. & 3.83 & 1.27 \\
7. Türkçe kelimelerle cümle kurabilirim. & 3.98 & 1.19 \\
8. Okuduğum Türkçe metinleri anlayabiliyorum. & 3.36 & 1.30 \\
9. Türkçenin Arapçadan daha zor olduğunu düşünüyorum. & 2.80 & 1.56 \\
10. Türkçe kelimeleri yazarken zorluk çekiyorum. & 2.34 & 1.44 \\
11. Türkçe dilbilgisi kurallarının zor olduğunu düşünüyorum. & 3.04 & 1.43 \\
12. Türkçenin Arapçaya uzak bir dil olduğunu düşünüyorum. & 3.04 & 1.55 \\
13. Türkçede Arapça kökenli kelimelerin olması Türkçeyi öğrenmemi kolay- & 4.21 & 1.19 \\
laştırdı. & 3.41 & 1.58 \\
14. Türkçe dersi almadan Türkçeyi öğrenmem daha zor olacaktır. & &
\end{tabular}


Anket sorularına verilen cevaplar değerlendirildiğinde Tablo 4'te 13. maddenin (4.21) $\bar{X}$ değeri 4.21-5.00 aralığında olduğundan öğrenciler, madde görüşüne tamamen katılmışlardır. Öğrenciler, Türkçede Arapça kökenli sözcük varlığının onların Türkçe öğrenme sürecini kolaylaştırdığını ifade etmişlerdir. Anketin 1, 2, 3, 4, 5, 6, 7 ve 14. maddelerin $\bar{X}$ değeri 3.41-4.20 aralığında olduğundan öğrenciler bu madde görüşlerine katılma eğilimi göstermişlerdir. Türkçe öğrenme sürecinde göçmen öğrenciler; yeterli sayıda kitabı olma, öğretmenlerini yeterli görme, Türkçe konuşmada zorluk yaşamama ve fırsat buldukça Türkçe konuşma görüşlerine katılmışlardır. Öğrenciler, Arapça metinleri Türkçeye çevirebilecekleri, duygu düşüncelerini Türkçe anlatabilecekleri, Türkçe cümle kurabilecekleri ve Türkçe dersi almadan Türkçe öğrenemeyecekleri görüşüne de katılmışlardır. Anketin 8, 9, 11 ve 12. maddelerin $\bar{X}$ değeri 2.61-3.40 aralığında olduğundan öğrenciler, bu maddelere kısmen katılma eğiliminde görüş bildirmişlerdir. Öğrencilerin kısmen katıldıkları görüşler; okudukları Türkçe metinleri anlama, Türkçenin Arapçadan daha zor olması, Türkçe dilbilgisi kurallarının zorluğu ve Türkçenin Arapçaya uzak bir dil olmasıdır. Anketin 10.maddesinin $\bar{X}$ değeri 1.812.60 aralığında olduğundan öğrenciler bu madde görüşüne katılmamaktadır. Bu bulgudan öğrencilerin Türkçe kelimeleri yazarken zorluk yaşamadıkları anlaşılmaktadır.

\section{Göçmen Çocukların Cinsiyet Değişkenine Göre Türkçe Öğreniminde Yaşadık- ları Problemlere İlişkin Elde Edilen Sonuçlar}

Araştırmada göçmen çocukların Türkçe öğrenme sürecinde yaşadıkları problemlere ilişkin elde edilen sonuçlar cinsiyet değişkenine göre analiz edilmiştir. Analiz sonucunda sadece $\mathrm{p}<.005$ düzeyinde anlamlı farklılık oluşturan maddeler ele alınmış olup diğer maddelere tabloda yer verilmemiştir. Göçmen çocukların Türkçe öğreniminde yaşadıkları problemlerin cinsiyet değişkenine göre dağılımına ilişkin elde edilen sonuçlar Tablo 5'te verilmiştir.

Tablo 5. Göçmen Çocukların Cinsiyet Değişkenine Göre Türkçe Öğreniminde Yaşadıkları Problemlerin Dağılımına İlişkin Elde Edilen Sonuçlar

\begin{tabular}{lccccccc}
\hline & \multicolumn{2}{c}{ Erkek } & \multicolumn{2}{c}{ Kız } & t & \multirow{2}{*}{$\mathrm{p}$} \\
\cline { 2 - 5 } & $\overline{\mathrm{X}}$ & SS & $\overline{\mathrm{X}}$ & SS & & \\
\hline Arapça metinleri Türkçeye çevirebilirim & 3.20 & 1.35 & 3.91 & 1.25 & $3.415^{*}$ & 0.001 \\
\hline${ }^{*} \mathrm{p}<.005$ & & & & & &
\end{tabular}

Türkçe öğrenme sürecinde yaşanılan zorluklarda, öğrencilerin cinsiyet değişkenine göre $\mathrm{p}<.005$ düzeyinde anlamlı bir farklılık görülmüştür. Tablo 5 değerlendirildiğinde araştırmada uygulanan anketin sadece 7 . maddesinde cinsiyet değişkenine göre anlamlı bir farklılık görülmüştür ( $\mathrm{t}=3.415$ ve $\mathrm{p}<.001)$. Kız öğrenciler, "Arapça metinleri Türkçeye çevirebilirim." görüşüne erkeklerden daha çok katılmışlardır. Buna göre, Arapça-Türkçe çeviri yapabilme görüşünde kız öğrencilerin öz güvenlerinin erkek öğrencilerden daha fazla olduğu söylenebilir. 


\section{Göçmen Çocukların Türkçe Öğreniminde Seslendirmede Zorlandıkları Sesli ve Sessiz Harfler}

Araştırmada, göçmen çocukların Türkçe öğrenme sürecinde sesli ve sessiz harfleri seslendirmede zorluk yaşadıkları bulgusuna ulaşılmıştır. Göçmen çocukların Türkçe öğreniminde seslendirirken zorlandıkları sesli harflere ilişkin elde edilen sonuçlar Tablo 6'da verilmiştir.

Tablo 6. Göçmen Çocukların Türkçe Öğreniminde Seslendirmede Zorlandıkları Sesli Harflere İlişkin Elde Edilen Sonuçlar

\begin{tabular}{lccc}
\hline & & f & \% \\
\hline & a & 3 & 1.9 \\
& e & 5 & 3.1 \\
Seslendirmede zorlanilan sesli harfler & 1 & 10 & 6.2 \\
& i & 42 & 26.2 \\
& o & 2 & 1.2 \\
& $\ddot{o}$ & 49 & 30.6 \\
& u & 45 & 28.1 \\
& $\ddot{u}$ & 108 & 67.5 \\
\hline
\end{tabular}

Tablo 6 incelendiğinde öğrencilerin sesli harfler arasında en çok ü harfini seslendirmede zorluk yaşadığı tespit edilmiştir. Öğrenciler, "ü" sesinden sonra frekans sıklığına göre sırasıyla "ö-u-i-ı-e-a-o" harflerini seslendirmede zorluk yaşadıklarını ifade etmişlerdir.

Veri analizi sonucunda öğrencilerin seslendirmede zorlandıkları sessiz harfler de tespit edilmiştir. Öğrencilerin seslendirmede zorlandıkları sessiz harflere ilişkin elde edilen sonuçlar, Tablo 7'de verilmiştir. 
Tablo 7. Göçmen Çocukların Türkçe Öğreniminde Seslendirmede Zorlandıkları Sessiz Harflere İlişkin Elde Edilen Sonuçlar

\begin{tabular}{|c|c|c|c|}
\hline & & $\mathbf{f}$ & $\%$ \\
\hline \multirow{21}{*}{ Seslendirmede zorlanılan sessiz harfler } & $\mathrm{b}$ & 6 & 3.7 \\
\hline & $\mathrm{c}$ & 11 & 6.9 \\
\hline & ç & 40 & 25,0 \\
\hline & $\mathrm{d}$ & - & - \\
\hline & $\mathrm{f}$ & 7 & 4.4 \\
\hline & $\mathrm{g}$ & 6 & 3.7 \\
\hline & $\breve{\mathrm{g}}$ & 84 & 52.5 \\
\hline & $\mathrm{h}$ & 13 & 8.1 \\
\hline & $\mathrm{j}$ & 46 & 28.7 \\
\hline & $\mathrm{k}$ & 2 & 1.2 \\
\hline & 1 & 6 & 3.7 \\
\hline & $\mathrm{m}$ & 6 & 3.7 \\
\hline & $\mathrm{n}$ & 6 & 3.7 \\
\hline & $\mathrm{p}$ & 20 & 12.5 \\
\hline & $\mathrm{r}$ & 23 & 14.4 \\
\hline & $\mathrm{s}$ & 7 & 4.4 \\
\hline & $\mathrm{s}$ & 62 & 38.7 \\
\hline & $\mathrm{t}$ & 19 & 11.8 \\
\hline & $\mathrm{v}$ & 9 & 5.6 \\
\hline & $\mathrm{y}$ & 10 & 6.2 \\
\hline & $\mathrm{z}$ & 15 & 9.4 \\
\hline
\end{tabular}

Tablo 7 incelendiğinde öğrencilerin sessiz harfler arasında en çok " $\breve{g}$ " harfini seslendirmede zorluk yaşadığ sıklığına göre sırasılla, "ş-j-ç-r-p-t-z-h-c-y-v-f-s-l-m-n-g-b-k" harflerini seslendirmede zorluk yaşadıkları bulgusuna ulaşılmıştır. Tablo 7'de öğrencilerin " $\mathrm{d}$ " harfini seslendirmede hiç zorluk yaşamadığı bulgusuna ulaşılmıştır.

\section{Sonuç, Tartışma ve Öneriler}

Araştırma sonucunda göçmen öğrencilerin Türkçe öğreniminde yaşadığı problemlere ilişkin bulgulara ulaşılmıştır. Araştırmaya 86 erkek ve $74 \mathrm{kız}$ olmak üzere toplam 160 öğrenci katılmıştır. Araştırmada Suriyeli göçmen öğrencilerin Türkçe öğrenme sürecinde sözlü anlatım, okuma-anlama, yazılı anlatım alanlarının yanı sıra üç öğrenme 
alanın tümünde de zorluk yaşadığı sonucuna ulaşılmıştır. Bu üç öğrenme alanında öğrenciler, en çok sözlü anlatım alanında sonra sırası ile okuma-anlama ve yazılı anlatımda zorluk yaşamışlardır. Buradan öğrencilerin yazma becerisine kıyasla konuşma becerilerinde daha çok zorluk yaşadıkları söylenebilir. Boylu ve Işık (2019) araştırmalarında Suriyeli çocukların Türkçedeki dört dil becerisinden okuma becerisinde başarılı, yazma becerisinde ise zayıf oldukları sonucuna ulaşmıştır.

Araştırmada öğrencilerin Türkçe öğrenme sürecinde zorluk yaşadığı öğrenme alanları, cinsiyet değişkenine göre de incelenmiştir. Cinsiyet değişkenine göre okuma-anlamada, erkek öğrencilerin (\%31.4) kız öğrencilere (\%9.5) oranla daha çok zorluk yaşadıkları, yazılı anlatımda kız öğrencilerin (\%16.2) erkek öğrencilere (12.8) göre daha çok zorlandıkları ve sözlü anlatım alanında kız öğrencilerin (\%39.2) erkek öğrencilere (\%20.9) göre daha çok zorlandıkları anlaşılmaktadır. Anketteki üç öğrenme alanında yaşanılan zorluklar cinsiyet değişkenine göre değerlendirildiğinde, kızlar (\%35.1) ve erkeklerin (\%34.9) birbirine yakın oranda olduğu görülmektedir.

Göçmen çocukların Türkçe öğreniminde yaşadıkları problemlere ilişkin değişken sonuçlara ulaşılmıştır. Öğrenciler, Türkçede Arapça kökenli benzer kelimelerin yer almasından dolayı bu yapıdaki kelimelerin Türkçe öğrenme sürecini kolaylaştırdığını düşünmektedir. Dil aktarımının sıklıkla meydana geldiği durumlardan biri de öğrencilerin zaten bildikleri bir dilin bir özelliği ile geliştirdikleri diller arası bir özellik arasindaki benzerlik duygusudur (Larsen-Freeman, 1991). Öğrenciler, Türkçe öğrenme sürecinde; öğretim kitaplarını ve öğretmenlerini yeterli görmekte, Türkçe konuşmada zorluk yaşamamakta ve fırsat buldukça Türkçe konuşmaktadır. Ancak Akış (2009) yabancılara Türkçe öğretimi alanında, bu alanda öğretmenleri yetiştirecek öğretim elemanı ve öğretim araçlarının yetersizliğinin ciddi bir problem olduğunu belirtmektedir.

Araştırma bulgularından öğrencilerin Arapça metinleri Türkçe çeviri yapabildikleri, duygu düşüncelerini Türkçe anlatarak Türkçe cümle kurabildikleri anlaşılmaktadır. Ancak öğrenciler Türkçe dersi almadan Türkçe öğrenemeyecekleri görüşüne de sahiptirler. Okudukları Türkçe metinleri anlama, Türkçenin Arapçadan daha zor olması, Türkçe dilbilgisi kurallarının zorluğu ve Türkçenin Arapçaya uzak bir dil olması ile ilgili görüşlere öğrenciler net bir katılım göstermemişlerdir.

Göçmen çocukların Türkçe öğreniminde yaşadıkları problemlerin cinsiyet değişkenine göre ilişkin anket maddelerinden sadece "Arapça metinleri Türkçeye çevirebilme" görüşünde anlamlı bir farklılık saptanmıştır. Bu farklılığa göre kız öğrencilerin Arapça metinleri Türkçeye çevirebilme görüşüne daha çok katıldıkları anlaşılmaktadır.

Araştırmada ulaşılan bulgulardan biri de göçmen öğrencilerin sesli ve sessiz harfleri seslendirme durumlarıdır. Suriyeli göçmen öğrenciler, sesli harfler arasında en çok "ü ve ö" harfini seslendirmede zorluk yaşamaktadır. Öğrencilerin seslendirmede zorluk yaşadığı diğer sesli harfler sırasıyla "u-i-1-e-a-o" harfleridir. Öğrenciler, sessiz 
harfler arasında en çok " $\breve{g}$ " harfini seslendirmede zorluk yaşamaktadır. Öğrencilerin zorlandıkları diğer sessiz harfler sırasıyla "ş-j-ç-r-p-t-z-h-c-y-v-f-s-l-m-n-g-b-k" harfleridir. Araştırmada öğrencilerin " $\mathrm{d}$ " harfini seslendirmede hiç zorluk yaşamadığı sonucuna ulaşılmıştır. Moralı (2018) da çalışmasında Suriyeli çocukların telaffuzlarında ciddi problemler olduğunu, Arapça-Türkçe arasındaki alfabe farklılığını ve bunun bir yansıması olarak da çocukların ünlü-ünsüz harflerde zorlandığını belirtmiştir. Hinofotis ve Baily (1980) benzer biçimde İngilizceyi ikinci dil olarak öğrenenlerin iletişim sürecinde en çok gerçekleştirdikleri hatanın telaffuz olduğunu ve öğrencilerin kelime bilgisinin olmadığını ifade etmiştir.

Araştırma sonucunda, Türkçe öğretiminin daha etkili yürütülebilmesi için öğretim sürecinde dil becerisi öğrenme alanlarından konuşma becerisine yönelik etkinliklere daha fazla yer verilmesi, sesli ve sessiz harflerin öğretimini pekiştirecek seslendirme çalışmalarının yapılması önerilmektedir.

\section{Kaynakça}

Akış, İ. (2009). Türkçenin yabancı dil olarak öğretimi ile ilgili ana sorunlar [Bildiri sunumu] 8. Dünyada Türkçe Öğretimi Sempozyumu Bildirimleri Ankara: Ankara Üniversitesi. s. 202-203.

Alyılmaz, S. (2018). Türkçe öğretiminde hedef kitlenin/ "öğrenen" in önemi. Uluslararası Türkçe Edebiyat Kültür Dergisi, 7(4), 2452-2463.

Al-Qdah, T. and Lacroix, M. (2010). Iraqi refugees in Jordan: Lessons for practice with refugees globally. International Social Work, 54(4), 521-534.

Avc1, Y. E., Koçoğlu, E. ve Ekici, Ö. (2013). Göçün eğitim ve eğitim yönetimine etkisine ilişkin okul yöneticilerinin görüşleri (Diyarbakır ili örneği). International Journal of Social Science, 6(2), 91-105.

Aykırı, K. (2017). Sınıf öğretmenlerinin sınıflarındaki Suriyeli öğrencilerin eğitim durumlarına ilişkin görüşleri. Turkish Journal of Primary Education, 2, 44-56.

Bakır, S. (2014). Türkiye'deki yabancılara Türkçe öğretim merkezleri ve Atatürk Üniversitesi Dil Eğitimi Uygulama ve Araştırma Merkezi. A. Ü. Türkiyat Araştırmaları Enstitüsü Dergisi (TAED), 5, 435-456

Barın, E. (1992). Yabancılara Türkçenin Öğretiminde Bir Metod Denemesi (Yayınlanmış YL Tezi). Gazi Üniversitesi, Ankara

Beyazova-Seçer, A. (2017). Seeking Education Beyond Refuge: An Analysis of Syrian Parents Perspectives of Their Children's Education in İstanbul. (Doktora Tezi) Boğaziçi Üniversitesi Sosyal Bilimler Enstitüsü Eğitim Bilimleri Anabilim Dalı, İstanbul. YÖK Tez Merkezi Veri Tabanı.

Boylu, E., ve Işık, P. (2019). Suriyeli mülteci çocuklara yabancı dil olarak Türkçe öğretenlerin yaşadıkları durumlara ilişkin görüşleri. Gazi Üniversitesi Eğitim Fakültesi Dergisi, 39(2), 895-936. 
Brown, J., Miller, J. and Mitchell, J. (2006). Interrupted schooling and the acquisition of literacy: Experiences of Sudanese refugees in Victorian secondary schools. Australian Journal of Language and Literacy, 29(2), 150-162.

Candaş Karababa, Z. C. (2009). Yabancı dil olarak Türkçenin öğretimi ve karşılaşılan sorunlar. Ankara Üniversitesi Eğitim Bilimleri Fakültesi Dergisi, 42(2), 265-277.

Cin, G. (2018). Suriyeli öğrencilere eğitim veren sını öğretmenlerinin yaşadıkları sorunlar ve psikolojik sağlamlllık düzeyi: Adana ili örneği (Yayımlanmamış yüksek lisans tezi). Çă̆ Üniversitesi Sosyal Bilimler Enstitüsü.

Er, O., Biçer, N. ve Bozkırlı, K. Ç. (2012). Yabancılara Türkçe öğretiminde karşılaşılan sorunların ilgili alan yazını ışığında değerlendirilmesi. Uluslararası Türkçe Edebiyat Külttür Eğitim (TEKE) Dergisi, 1(2), 51-69.

Ereş, F. (2015). Türkiye'de Göçmen Eğitimi Sorunsalı ve Göçmen Eğitiminde Farklılığın Yönetimi, Çankırı Karatekin Üniversitesi Sosyal Bilimler Enstitüsü Dergisi, 6(2), 17- 30.

Erkuş, A. (2005). Bilimsel araştırma sarmalt. Ankara: Seçkin Yayınevi.

Fansa, M. (2015). Geçici eğitim merkezlerindeki yabancı öğrencilere yönelik Türkçe öğretiminde karşılaşılan sorunlar ve çözüm önerileri [Bildiri sunumu]. Antalya, 25. Ulusal Eğitim Bilimleri Kongresi , s. 752.

Gigm. (29.05.2020). Geçici Koruma, İstatistikler. https://www.goc.gov.tr/gecicikoruma5638

Göçer, A. ve Moğul, S. (2011). Türkçenin yabancı dil olarak Türkçe öğretimi ile ilgili çalışmalara genel bir bakış. Turkish Studies-International Periodical for the Languages, Literature and History of Turkish or Turkic, 6 (3), 797-810.

Gözübüyük Tamer, M. (2017). Geçici koruma kapsamındaki Suriyeli çocukların Trabzon devlet okullarındaki durumu. Göç Dergisi, 4(1), 119-152.

Gunderson, L. (2007). English only instruction and immigrant students in secondary schools: A critical examination. Mahwah, NJ: Lawrence Erlbaum Associates.

Hinofotis, F. and Baily, K. (1980). American undergraduate reaction to the communication skills of foreign teaching assistants TESOL "80: Building Bridges. Research and Practice in TESL", Alexandria, V.A. 124-125

Kahriman, R., Dağtaş, A., Çapoğlu, E. ve Ateşal, Z. (2013). Yabancılara Türkçe öğretimi kaynakçaS1. Türük Dil, Edebiyat ve Halkbilimi Araştırmaları Dergisi, 1(1), 80-132.

Kanu, Y. (2008). Educational needs and barriers for African refugee students in Manitoba. Canadian Journal of Education, 31(4), 915-940.

Larsen Freeman and Long, M. (1991). An Introduction to Second Language Research. New york: Longman.

Levent, F. ve Çayak, S. (2017). Türkiye'deki Suriyeli öğrencilerin eğitimine yönelik okul yöneticilerinin görüşleri. Hasan Ali Yücel Eğitim Fakültesi Dergisi, 14-1(27), 21-46. 
Mcbrien, J. L. (2005). Educational needs and barriers for refugee students in the United States: A review of the literature. Review of Educational Research, 75(3), 329-364.

MEB. (2017). İzleme ve değerlendirme raporu. Ankara. http:/ /hbogm.meb.gov.tr/dosyalar/izlemedegerlendirmerapor $/ 20171 /$ mobile/index.html\#p=1 adresinden alınmıştır

Mercan Uzun, E. ve Bütün, E. (2016). Okul öncesi eğitim kurumlarındaki Suriyeli sığınmacı çocukların karşılaştıkları sorunlar hakkında öğretmen görüşleri. Uluslararası Erken Çocukluk Ĕ̆itimi Çalışmaları Dergisi, 1(1), 72-83.

Moralı, G. (2018). Suriyeli mülteci çocuklara Türkçenin yabancı dil olarak öğretiminde karşılaşılan sorunlar. OPUS-Uluslararası Toplum Araştırmaları Dergisi, 8(15), 1426-1449. DOI: 10.26466/opus. 443945

Nachmias, C. F. ve Nachmias, D. (1996). Research methods in the social sciences (5th ed.). London: St. Martin's Press Inc

Sakız, H. (2016). Göçmen çocuklar ve okul kültürleri: Bir bütünleştirme önerisi. Göç Dergisi, 3(1), 65-81.

Saklan, E. ve Erginer, A. (2017). Classroom management experiences with Syrian refugee students. Education Journal, 6(6), 207-214.

Seymen, H. ve Tok, M. (2015). İleri düzey yabancı uyruklu öğrencilerin zorlandıkları kültürel dil unsurlarının tespiti ve sınıflandırılması. Uluslararası Türkçe Edebiyat Kültür Eğitim Dergisi, 4(3), 1188-1212.

Stewart, J. (2007). Children affected by war: A bioecological investigation into their psychosocial and educational needs. (Unpublished Doctoral Dissertation). Winnipeg, MB. University of Manitoba.

Stewart, J. (2011). Supporting refugee children: Strategies for teachers. University of Toronto Press: Toronto.

Tanay Akalın, A. (2016). Türkiye'ye gelen Suriyeli göçmen çocukların eğitim sorunları. (Yayımlanmamış yüksek lisans tezi). İstanbul Aydın Üniversitesi Sosyal Bilimler Enstitüsü, İstanbul.

Topsakal, C., Merey, Z. ve Keçe, M. (2013). Göçle gelen ailelerin çocuklarının eğitim-öğrenim hakkı ve sorunları üzerine nitel bir çalışma. Uluslararası Sosyal Araştırmalar Dergisi. 6 (27). 546-560.

Tösten, R., Toprak, M. and Kayan, M. S. (2017). An investigation of forcibly migrated Syrian refugee students at Turkish public schools. Universal Journal of Educational Research, 5(7), 1149-1160.

Whiteman, R. (2005). Welcoming the stranger: A qualitative analysis of teachers' views regarding the integration of refugee pupils into schools in Newcastle upon Tyne. Educational Studies, 31(4), 375-391. 